\title{
8. The Pacific Solution: The European Union's Intellectual Property Rights Activism in Australia's and New Zealand's Sphere of Influence
}

\author{
Michael Blakeney
}

\section{Introduction}

This chapter describes the activities of the European Union (EU) in providing technical assistance to Pacific Island countries in relation to traditional knowledge (TK), and the implications for Australian and New Zealand development cooperation activities in what was hitherto regarded as their 'lake'. Agriculture is the issue which has dominated Australia's and New Zealand's trade agenda, and intellectual property rights (IPRs), whether trade related or otherwise, are very much a subordinate issue. Both nations were foundation members of the Cairns Group of nineteen agricultural exporting countries which was formed in 1986, at the time of the Uruguay Round of the General Agreement on Tariffs and Trade (GATT), to agitate for global agricultural trade reform. The Cairns Group has been forthright in criticising the European Community (EC), the United States and Japan as protecting their agricultural markets through a combination of high tariffs on agricultural imports and subsidies to their farm sectors. This condemns agricultural exporters in developing countries in Latin America, South East Asia and Oceania to 'the role of residual suppliers to their traditional markets' and crowds them out of most other markets. ${ }^{1}$

The 35th Cairns Group Ministerial Meeting at Punta del Este, Uruguay, from 19 to 20 April 2010 conceded that the Doha Development Agenda must remain the top priority of World Trade Organization (WTO) members, but that the Cairns Group will continue to push for global trade reform in agriculture, which it perceived as critical to the development deliverables of the Uruguay Round. ${ }^{2}$ In fact, the agriculture negotiations have been proceeding at a glacial pace and have not been assisted by the global financial crisis. An indication of Australia's

1 Cairns Group, Agricultural Trade and the Cairns Group <http://cairnsgroup.org>

2 35th Cairns Group Ministerial Meeting, Punta del Este, Uruguay, Communiqué (2010) <http://www. cairnsgroup.org/Pages/100420_communique.aspx?noredirect=1> 
ranking of negotiating priorities can be seen in its negotiation in 2007 of the Free Trade Agreement (FTA) with the United States in which it was perceived as bargaining away IPRs for access to United States agricultural markets. ${ }^{3}$

For the EU, on the other hand, the maintenance of agricultural protectionism does not seem to have abated, but it maintains a substantial IPRs agenda to underpin both its pharmaceutical and digital-based industries. Also, member states of the EU, such as France, Spain and Italy, have pioneered the use of geographical indications (GIs) to underpin agricultural niche markets. The EU played a significant role in having GIs included within the TRIPS Agreement. This inclusion was incomplete, as the articles concerned with GIs had a number of 'built-in agendas' which envisaged further negotiations to finalise this subject. Thus, Article 24.2 required the TRIPS Council to conduct a review of the operation of the GIs provisions within the first two years of entry into force of the WTO Agreement. Article 23.4 provided that in order to facilitate the protection of geographical indications for wines, negotiations shall be undertaken in the Council for TRIPS concerning the establishment of a multilateral system of notification and registration of geographical indications for wines eligible for protection in those Members participating in the system', and under Article 24.1 members agreed 'to enter into negotiations aimed at increasing the protection of individual geographical indications under Article 23'. The EU, together with Switzerland, has played an active role in pressing for an expansion of the scope of the GIs provisions of TRIPS. Australia and New Zealand, on the other hand, have been active opponents of this expansion.

The EU has also pursued its GIs agenda outside the TRIPS Council. In February 2003, the EC proposed to the WTO's Committee on Agriculture that it 'claw back' certain GIs which were being 'used by producers other than the rightholders in the country of origin'. ${ }^{4}$ The EC's approach to GIs in the context of the agriculture negotiations is complementary to the TRIPS negotiations. The EC explained that its objective was to negotiate 'specific commitments in order to guarantee fair market access opportunities for those wines, spirits and other agricultural and food-stuff products whose quality, reputation or other characteristics are essentially attributable to their geographical origin and traditional know-how'. ${ }^{5}$ As a follow-up to this proposal, in September 2003 a preliminary list of products (wines, spirits, cheeses and ham) which fell into this category was notified to the Committee. ${ }^{6}$ The claw-back proposal was strongly opposed by the same countries that were opposed to GIs extension in the TRIPS

3 See P Drahos et al, 'Pharmaceuticals, Intellectual Property and Free Trade: The Case of the US-Australia Free Trade Agreement' (2004) 22(3) Prometheus 243.

4 A Proposal For Modalities in the WTO Agriculture Negotiations, Specific Drafting Input by the EC, WTO Doc JOB(03)/12 (2003).

5 Ibid 3.

6 WTO Doc, above n 4. 
Council. The EC sought to allay concerns by referring to the 'grand-fathering' clause of Article 24.4, which would allow the use of protected GIs by producers in third countries, providing that they have done so for more than ten years prior to the signing of an amendment. ${ }^{7}$

Within the Committee on Agriculture the view has been strongly pressed that GIs protection is a matter for the TRIPS Council because the agriculture negotiations focus on food products, whereas proposed negotiations under TRIPS would cover all products including agricultural products and handicrafts. ${ }^{8}$ Certainly the WTO documents concerning the negotiations on agriculture over the past five years make no reference to GIs.

In urging their respective positions, both the EU and its antipodean opponents have sought to enlist third countries, particularly those in the large bloc of developing and least developed countries (LDCs), to their cause. However, as this chapter indicates, in the Pacific this rivalry has been played out in the field of traditional knowledge (TK) protection, which is perceived by Pacific Island countries as closer to their national interests.

\section{The Pacific Islands Perspective}

The Pacific Islands Forum ${ }^{9}$ is the key regional political organisation in the Pacific. Its annual meetings have mainly focused on regional trade and economic issues. The foundation members were: Australia, the Cook Islands, Fiji, Nauru, New Zealand, Tonga and Western Samoa. They have since been joined by Niue, Papua New Guinea, Kiribati, Tuvalu, Vanuatu, Solomon Islands, the Republic of the Marshall Islands, the Federated States of Micronesia, and Palau. New Caledonia and French Polynesia were granted associate membership in 2006. Current Forum observers include: Tokelau, Wallis and Futuna, American Samoa, Guam and the Commonwealth of Northern Marianas; Timor Leste has special observer status.

The 40th Forum, held in Cairns in August 2011, issued the Cairns Communiqué, which included the Cairns Compact on Strengthening Development Coordination in the Pacific; a Call to Action on Climate Change, in advance of Copenhagen; agreement to commence negotiations on a new regional trade and economic agreement; and the hosting of meetings to strengthen protection and management

7 See Geographical Indications - Communication from the European Communities, WTO Doc TN/IP/W/11 (2005).

8 See WTO, Agricultural Negotiations: Geographical Indications <http://www.wto.org/english/tratop_e/ agric_e/negs_bkgrnd21_ph2geog_e.htm>

9 Until 27 October 2000 it was known as the South Pacific Forum. 
of regional fisheries resources, and to improve energy security. ${ }^{10}$ The subsequent Forum, in Auckland, New Zealand, in September 2011 reaffirmed strong support for the Cairns Compact on Strengthening Development Coordination.

The Pacific Agreement on Closer Economic Relations (PACER) is an umbrella agreement between the Pacific Islands members of the Pacific Islands Forum and Australia and New Zealand. The agreement which was signed at Nauru on 18 August 2001, entering into force on 3 October 2002, established a framework for the future development of trade and economic relations across the Forum region as a whole. It envisaged a staged process of trade liberalisation, commencing with a free trade agreement in goods - the Pacific Island Countries Trade Agreement - among Pacific Island countries. Among other things, PACER provides for technical assistance to the Island country members in anticipation of future negotiations on a Forum-wide reciprocal free trade agreement (PACER-Plus). An underlying concern of the Forum Island countries is that the PACER-Plus agreement is being 'forced on them' by the currently dominant regional powers, Australia and New Zealand. ${ }^{11}$ The Forum Island countries have fought to have established as an independent body the Office of the Chief Trade Adviser (OCTA) to provide advice and support for the negotiation of PACER-Plus. Australia and New Zealand have apparently sought to use their contribution to the funding of the OCTA to restrict the activities of that office. ${ }^{12}$ The tension between Australia and New Zealand on the one hand and the Forum Island states on the other has created an opportunity of influence for the EU, which has announced its intention of negotiating Economic Partnership Agreements (EPAs) with the Pacific Island states. ${ }^{13}$

In July 2009, Papua New Guinea signed an interim EPA, followed by Fiji in December 2009. The situation of Fiji has also provided the EU with an opportunity to involve itself in Pacific affairs. On 2 May 2009, Fiji was suspended indefinitely from participation in the Pacific Forum because of the deteriorating human rights situation in the country. It remains outside the Pacific Forum. As one response, Fiji became the principal organiser of the Melanesian Spearhead Group (MSG), comprising Fiji, Papua New Guinea, the Solomon Islands and the Front de Libération Nationale Kanak et Socialiste of New Caledonia. The MSG had been founded as a political gathering in 1983, but became an

10 See Australian Government Dept. of Foreign Affairs and Trade, Pacific Islands Forum <http://www.dfat. gov.au/geo/spacific/regional_orgs/spf.html>

11 See J Kelsey, Big Brothers Behaving Badly: The Implications for the Pacific Islands of the Pacific Agreement on Closer Economic Relations (PACER) (2004) < http://www.bilaterals.org/IMG/pdf/pang_big_brother.pdf.> 12 See Senator L Rhiannon, Adjournment Speech: 'Pacific Trade Negotiations (2011) < http://lee-rhiannon. greensmps.org.au/content/parliament/speech/lees-speech-on-pacific-trade-negotiations > See also D Flitton, 'Pacific Islands Accuse Australia's Aid Agency of Coercion', The Age (online), 29 August 2011, <http://www. theage.com.au/national/pacific-islands-accuse-australias-aid-agency-of-coercion-201 10828-1jgnv.html>

13 See European Commission, Negotiations and Agreements (2012) <http://ec.europa.eu/trade/wider-agenda/ development/economic-partnerships/negotiations-and-agreements/\#pacific/> 
international organisation on 23 March 2007. MSG members are the signatories of a preferential trade agreement between them. On the occasion of the 40th anniversary of the Pacific Islands Forum in September 2011, Fiji's military ruler, Frank Bainimarama, took the opportunity to organise a meeting with a number of Pacific Island states in Nadi. It was attended by the prime ministers of Papua New Guinea, Solomon Islands and Tuvalu, as well as the foreign ministers of Nauru and Timor Leste. ${ }^{14}$

The exclusion of Fiji from the Pacific Islands Forum has caused Fiji and MSG members to look to the People's Republic of China to fund the construction of a Secretariat building in Vanuatu. And, as is mentioned below, the EU provided technical assistance to the MSG to allow it to promulgate in 2011 a collaborative agreement providing for the protection of TK and expressions of culture.

Finally, it should be noted that an assumption of the Pacific development cooperation programmes of the EU and of Australia and New Zealand is that WTO membership is a desirable objective for Pacific Island states. However, some of those states have begun to question whether this is indeed in their best interests. Vanuatu, which completed its WTO accession process in 2001, has been reported to have 'put it on hold' because of the wide- ranging trade concessions it was required to make. ${ }^{15}$ Similarly, Samoa and Tonga are reported to be deterred by the trade concessions which they have been obliged to offer. ${ }^{16}$ The EU initiatives in relation to TK and GIs, underpinned by its EPAs, can be seen as an attempt to demonstrate the advantages of WTO engagement for the Pacific Island states.

\section{An International TK Instrument}

The Pacific region has been a global pioneer of initiatives for the protection of TK. The first regional instrument dealing with the protection of TK was the Suva Declaration which was issued by the Regional Consultation on Indigenous Peoples' Knowledge and Intellectual Property Rights, held in April 1995. The declarants committed themselves to raising public awareness of the dangers of expropriation of indigenous knowledge and resources; encouraging chiefs, elders and community leaders to play a leadership role in the protection of indigenous peoples' knowledge and resources; and to incorporating the concerns of indigenous peoples to protect their knowledge and resources in

14 R Callick, 'Fiji Casts Shadow on Pacific Forum', The Australian (online), 5 September $2011<\mathrm{http}: / /$ www. theaustralian.com.au/news/features/fiji-casts-shadow-on-pacific-forum/story-e6frg6z6-1226129262121>

15 J Kelsey, Acceding Countries as Pawns in a Power Play: A Case Study of the Pacific Islands (2007) <http:// uriohau.blogspot.com/2007/08/acceding-countries-as-pawns-in-power.html>

16 Ibid. 
legislation by including 'Prior Informed Consent or No Informed Consent' (PICNIC) procedures, and excluding the patenting of life forms. ${ }^{17}$ The Suva Declaration called for the initiation of a treaty 'declaring the Pacific Region to be a life forms patent-free zone' and for a moratorium on bioprospecting in the Pacific until appropriate protection mechanisms were in place. The final article of the Declaration called on France 'to stop definitively its nuclear testing in the Pacific and repair the damaged biodiversity'. ${ }^{18}$

Responding to a number of indigenous persons' declarations calling for the protection of TK which had followed the Rio Earth Summit in 1992, ${ }^{19}$ the World Forum on the Protection of Folklore was convened by the World Intellectual Property Organization (WIPO) and UNESCO in February 1996 in Phuket, Thailand, to explore issues concerning the preservation and protection of expressions of folklore. At that meeting the representatives of organisations of indigenous peoples called for the promulgation of an international convention to protect TK. In response, WIPO in its 1998-99 biennium instituted a schedule of regional fact-finding missions 'to identify and explore the intellectual property needs, rights and expectations of the holders of traditional knowledge and innovations, in order to promote the contribution of the intellectual property system to their social, cultural and economic development ${ }^{\prime}{ }^{20}$

In a Note dated 14 September 2000, the Permanent Mission of the Dominican Republic to the United Nations in Geneva submitted two documents on behalf of the Group of Countries of Latin America and the Caribbean calling for the creation of a Standing Committee on access to the genetic resources and TK of local and indigenous communities. 'The work of that Standing Committee would have to be directed towards defining internationally recognized practical methods of securing adequate protection for the intellectual property rights in traditional knowledge..'21 In 2000, WIPO established an Intergovernmental Committee on Intellectual Property and Genetic Resources, Traditional Knowledge and Folklore (IGC). At its first session, held in Geneva from 30 April to 3 May 2001, IGC member states determined the agenda of items on which work should proceed, and prioritised certain tasks. Principal among these was 'the development of "guide contractual practices," guidelines, and model intellectual property clauses for contractual agreements on access to genetic resources and benefit-sharing' ${ }^{22}$ This soft law approach to the protection of TK

17 Reproduced at UNDP Consultation on Indigenous Peoples' Knowledge and Intellectual Property Rights appendix $11<$ http://www.idrc.ca/cp/ev-30152-201-1-DO_TOPIC.html>

18 Ibid, art 10.1.

19 For example Mataatua Declaration (1993), Kari-Oca Declaration (1992), Julayabinul Statement (1993).

20 See WIPO, Report on Fact-finding Missions on Intellectual Property and Traditional Knowledge (1998-1999) $<$ http://www.wipo.int/tk/en/tk/ffm/report/final/> Cached, 9 March 2012.

21 See WIPO Doc, Traditional Knowledge and the Need to Give It Adequate Intellectual Property Protection, WIPO Doc WO/GA/26/9 (2000) annex I, 10.

22 See WIPO IGC Secretariat, Operational Principles for Intellectual Property Clauses of Contractual Agreements 
continued for a number of years. In August 2004, the IGC began to consider the 'objectives' and 'principles' which should animate the protection of $\mathrm{TK}^{23}$ and this task has continued through all the subsequent sessions of the IGC. ${ }^{24}$ A brief palpitation of enthusiasm on the international front was generated in October 2010, when the IGC identified its upcoming $17^{\text {th }}$ session, to be held from 6 tol0 December 2010, as the occasion for the first text-based discussion of the establishment of an international TK regime. The results of this session were not so exciting. An 'informal drafting group' was set up to provide a text on traditional cultural expressions (TCEs) for the next meeting of the IGC scheduled for 9 tol3 May $2011 .^{25}$

In relation to TK, matters were not as far advanced. An intersessional working group met from 21 to 25 February 2011 to discuss the latest draft of the Revised Objectives and Principles on TK. The report prepared by the working group for the May 2011 meeting of the IGC explained that the draft articles and comments, including specific texts suggested by experts, were noted ... and not adopted as such'. ${ }^{26}$

\section{Pacific Regional TK Initiatives}

Two early Pacific initiatives for the protection of TK were: the 2001 Model Law on Traditional Biological Resources, Innovations and Practices, developed by the Pacific Islands Forum; ${ }^{27}$ and the Model Law on Traditional Knowledge and Expressions of Culture (TKEC), completed in 2002 and subsequently endorsed by the Pacific Community Ministers for Culture of the Secretariat of the Pacific Community (SPC) for adoption by member countries. ${ }^{28}$ Despite their promulgation, neither of these instruments was implemented by national legislation. Apparently, the Pacific Island countries were urged by Australia and New Zealand to await international developments at WIPO.

The slow pace of these developments caused the Anglophone African countries at a diplomatic conference organised by the African Regional Intellectual

\footnotetext{
23 See WIPO IGC Secretariat, Protection of Traditional Knowledge: Overview of Policy Objectives and Core Principles, WIPO Doc WIPO/GRTKF/IC/7/5 (2004).

24 The most recent contribution in this regard is WIPO Doc, Protection of Traditional Cultural Expressions/ Cultural Expressions of Folklore. Revised Objectives and Principles, WIPO/GRTKF/IC/17/4Prov (2010).

25 See WIPO IGC Secretariat, Decisions of the Seventeenth Session of the IGC (2010) < http://www.wipo.int/ meetings/en/details.jsp?meeting_id=20207>

26 WIPO IGC Secretariat, Draft Articles on the Protection of Traditional Knowledge prepared at IWG 2, WIPO Doc WIPO/GRTKF/IC/18/7 (2011), para 2.

27 Founded in 1971 as the South Pacific Forum. In 2000, the name was changed to the Pacific Islands Forum 'to better reflect the geographic location of its members in the north and south Pacific'. Its members were: Australia, Cook Islands, Federated States of Micronesia, Fiji, Kiribati, Nauru, New Zealand, Niue, Palau, Papua New Guinea, Republic of Marshall Islands, Samoa, Solomon Islands, Tonga, Tuvalu and Vanuatu.

28 In addition to the Pacific Island states, SPC members included Australia, New Zealand and the USA.
} 
Property Organization (ARIPO) on 9 and 10 August 2010 in Swakopmund, Namibia, to promulgate a Protocol on the Protection of Traditional Knowledge and Expressions of Folklore. The Protocol is meant to "protect creations derived from the exploitation of traditional knowledge in ARIPO member states against misappropriation and illicit use through bio-piracy'. ${ }^{29}$ The African group of countries at WIPO have been in the forefront of agitation there to accelerate international negotiations for a TK instrument. The Swakopmund Declaration can be regarded as either a reflection of their appreciation of the realistic likelihood of an international solution or a means of accelerating the pace of developments at WIPO.

In March 2007, at a high-level meeting of the executives of the Pacific Islands Forum Secretariat (PIFS) and the SPC, it was decided that lead agency responsibility relating to the Model Law would move from the SPC to the PIFS. As a first step, the PIFS convened a workshop in June 2007 to determine member countries' technical assistance needs with regard to progressing the Model Law's implementation at the national level. The conclusions and recommendations of that workshop were subsequently endorsed by Forum trade ministers in August 2007. A Traditional Knowledge Implementation Action Plan ('Action Plan') was, in part, a response to member countries' requests for technical assistance as conveyed to the PIFS at the workshop. Its overall objective was to assist the Forum Island countries in their efforts to establish a regional infrastructure for TK that would consist of a mutual recognition and enforcement regime founded on uniform national legal systems of protection. As a first step, the Action Plan would assist the Forum Island countries to develop policy and draft legislation based on the Model Law on TKEC and the Model Law on Traditional Biological Resources framework. Then, as a second step, a regional system of TK protection would be developed.

The Action Plan was developed with the technical assistance of the TradeCom Facility of the EU. Two EU projects were implemented as part of a broad programme of technical assistance. The first project provided technical assistance for the establishment of national systems of protection for TK in six of the member states of the Pacific Islands Forum, namely the Cook Islands, Fiji, Kiribati, Palau, Papua New Guinea and Vanuatu. ${ }^{30}$ The terms of reference for the second project, concerning the formulation of a treaty for the reciprocal recognition of TK among the Melanesian Spearhead Group of countries (Fiji, Papua New Guinea, the Solomon Islands and Vanuatu), recognised that

29 See WIPO, Swalopmund Protocol on the Protection of Traditional Knowledge and Expressions of Folklore within the Framework of the African Regional Intellectual Property Organization (ARIPO) <http://www.wipo. int/wipolex/en/other_treaties/details.jsp?treaty_id=294>

30 Pacific Islands Forum Secretariat, Traditional Knowledge Implementation Action Plan (2009) <http:// www.forumsec.org.fj/resources/uploads/attachments/documents/Traditional\%20Knowledge \%20Action \% 20 Plan \%202009.pdf> 
... a global treaty for TK governance at international fora such as WIPO ...would present the best possible answer to the problem. However those processes are evolving slowly and are fraught with the political and diplomatic complexities of international negotiations. Running in parallel, a viable and faster alternative ... would be to consider reciprocal arrangements for recognition and enforcement between the MSG members ... While the focus for the MSG Secretariat at this time is clearly its own members, the MSG recognizes that ultimately the issue at hand is a global one and any future collective arrangement would not preclude other countries from the wider Pacific region to participate in the system. These developments would instruct and inform global treaty making processes currently taking place in institutions such as WIPO and possibly lead to engagement with other like-minded regions given the slow movements to conclude a global regime for TK at WIPO, WTO and CBD. ${ }^{31}$

\section{Australian, New Zealand and EU Negotiating Positions on TK}

The Pacific Island countries resort to EU assistance in relation to their TK protection agenda may derive from the respective negotiating positions of the EU, Australia and New Zealand in the various international fora considering this subject. Australia and New Zealand were two of only four countries (together with Canada and the United States) which originally voted against the United Nations Declaration on the Rights of Indigenous Peoples (UNDRIP) which was adopted by the General Assembly of the United Nations on 13 September 2007. Some 143 member states voted in favour of UNDRIP, a non-binding text which sets out the rights of indigenous peoples to 'maintain and strengthen their own institutions, cultures and traditions, and to pursue their development in keeping with their own needs and aspirations'. Article 31 of UNDRIP recognises the rights of indigenous peoples to maintain, control, protect and develop their intellectual property over their cultural heritage, traditional knowledge and traditional cultural expressions. The opposition of Australia and New Zealand, Canada and the United States attracted considerable opprobrium and could not have been very encouraging for the Pacific Island countries pursuing an international TK regime.

31 TradeCom Facility Program 'Technical Assistance to Study the Feasibility of a Reciprocal Recognition and Enforcement Mechanism for TK between Fiji, Papua New Guinea, Solomon Islands and Vanuatu', (AOR162-P177) [on file with author]. 
Senator Marise Payne explained in a speech in the Australian Senate on 10 September 2007 the various reasons for the Australian Government's opposition to UNDRIP. She explained that 'as our laws here currently stand, we protect our Indigenous cultural heritage, traditional knowledge and traditional cultural expression to an extent that is consistent with both Australian and international intellectual property law, and we are not prepared to go as far as the provisions in the text of the draft declaration currently do on that matter' ${ }^{32}$ In other words, Senator Payne seemed to indicate that the Australian Government was opposed to any sui generis protection of TK. She also indicated the Australian Government's opposition to 'the inclusion in the text of an unqualified right of free, prior and informed consent for indigenous peoples on matters affecting them' because the text did 'not acknowledge the rights of third parties - in particular, their rights to access indigenous land and heritage and cultural objects where appropriate under national law' ${ }^{33}$

New Zealand's Māori Affairs minister, Parekura Horomia, was reported as criticising UNDRIP as little more than a wish list. ${ }^{34}$ On the other hand, the country's Māori Party co-leader Tariana Turia was very critical of the New Zealand Government's position in opposing a Declaration which promotes 'merely a minimum standard of human rights for Māori'. ${ }^{35}$

With the change of government in Australia, Prime Minister Kevin Rudd announced on 3 April 2009 Australian support for the Declaration. ${ }^{36} \mathrm{New}$ Zealand followed suit on 19 April 2010, also after a change of government. ${ }^{37}$

Within WIPO, the $18^{\text {th }}$ session of the IGC met from 9 to 13 May 2011 in Geneva to consider the latest draft of the Revised Objectives and Principles for the Protection of Traditional Knowledge. ${ }^{38}$ Some perspective on the current negotiating positions of Australia and New Zealand can be gleaned from delegations' submissions on this document.

The Australian delegation considered that, without prejudice to any position on particular elements, the Objectives and Principles in Parts I and II should support and provide guidance to any suggested working text on the substantive

32 Commonwealth, Parliamentary Debates, Senate, 18 September 2007, 53-54 (Marise Payne).

33 Ibid.

34 New Zealand Government, 'Press Release: Māori Party's Head in the Clouds' (Press Release, 14 September 2007) <http://www.scoop.co.nz/stories/PA0709/S00272.htm>

35 'New Zealand Indigenous Rights Stance "Shameful" — Māori Party', Stuff (online), 14 September 2007 $<$ http://www.stuff.co.nz/archived-stuff-sections/archived-national-sections/korero/45362>

36 United Nations News Centre, Experts Hail Australia's Backing of UN Declaration of Indigenous People's Rights (2009) <http://www.un.org/apps/news/story.asp?NewsID=30382>

37 T Watkins, 'New Zealand does U-turn on Rights Charter', Stuff (online), 20 April $2010<$ http://www. stuff.co.nz/national/politics/3599153/NZ-does-U-turn-on-rights-charter>

38 WIPO IGC Secretariat, above n 26. 
provisions contained in Part III. ${ }^{39}$ It noted that the lack of agreement or consensus on elements of the Objectives and Principles made discussion of Part III very difficult'.$^{40}$ Specifically:

With respect to part III, in general, it noted that references to 'Articles' resembled draft treaty text and pre-empt discussion about the form and status of any international legal instrument which would ensure the protection of TK. It noted the lack of consensus on the need for a legally binding instrument, and called for further general discussion at an appropriate time on the adoption of prescriptive principles that focused on conferring legally enforceable rights in light of the core General Guiding Principle (g) 'respect for and cooperation with other international and regional instruments and processes' ${ }^{41}$

This negotiating position would seem to be out of sympathy with the aspirations of the Pacific Island countries for a legally enforceable international TK regime.

The New Zealand delegation, together with those of Japan and Switzerland, suggested that in-depth examination of policy objectives and principles was the prerequisite for the discussion on the substantive provisions' ${ }^{4}{ }^{42}$

The submission of the delegation of the EU and its member states indicates a more sympathetic position. It suggested that the Policy Objectives 'had become overly long, detailed and complicated', and expressed the view that 'the aim of the objectives should be to set out an overarching statement of what the Committee thought this instrument should do and not how it should be done' ${ }^{43}$ It agreed that there was a need to find a proper balance between the holders of TK and users in society at large, but that the proposed Objectives, Principles and substantive articles 'needed to respect the existing international regimes and in particular the IP regime' ${ }^{44}$ Finally, the delegation was of the opinion that the eventual protection of TK could not prevail in any way over the existing conventional IP regimes. ${ }^{45}$ This final submission will raise problems for those who consider that TK has a human rights content. ${ }^{46}$ Resolution 2000/7 of the United Nations Sub-Commission on Human Rights in Article 3 reminds all governments 'of the primacy of human rights obligations over economic policies and agreements'. Governments are requested in Article 6 to integrate into their

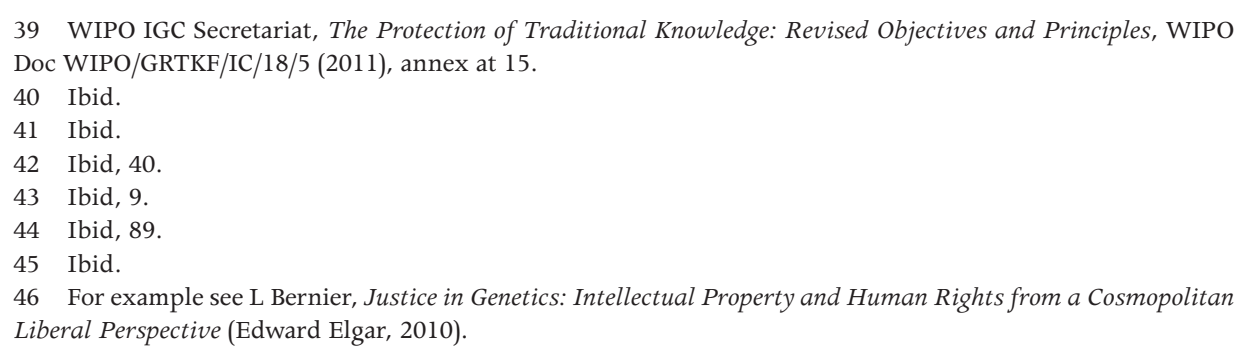


national and local legislations and policies 'provisions, in accordance with international human rights obligations and principles that protect the social function of intellectual property'.

Australia and New Zealand, together with Canada, Norway and the United States, have taken a lead at the IGC in proposing in May 2010 the objectives, principles and substantive provisions for international legislation which might be promulgated on the protection of genetic resources. ${ }^{47}$ The IGC adopted this as a working draft and invited comments on it from other delegations. Chile's and Colombia's comments from the perspective of developing countries were that the proposals lacked both specificity and the crucial obligation of sharing benefits from the utilisation of others' genetic resources. ${ }^{48}$

In 2002, the EU had submitted to the TRIPS Council that the disclosure of origin of genetic resources involved in patent applications should be a mandatory obligation. ${ }^{49}$ This was reiterated by the EU in May 2005 in its submission to the IGC on the 'Disclosure of Origin or Source of Genetic Resources and Associated Traditional Knowledge in Patent Applications'. It argued that 'there are good reasons for an obligation to disclose that an invention is directly based on traditional knowledge associated with the use of genetic resources' ${ }^{50}$ The African group of countries endorsed this EU proposal in its response to the Australia/New Zealand May 2010 submission to the IGC. ${ }^{51}$ The African group also proposed the principle that IPRs and obligations be clarified 'with respect to the protection of traditional knowledge, genetic resources and traditional cultural expressions and certainty and clarity for prior informed consent and fair and equitable benefit sharing' ${ }^{52}$

In general it would seem that the negotiating positions taken by the EU on TK and genetic resources are closer to the interests of the Pacific Island countries than those taken by Australia and New Zealand. The EU does not have the complication of significant indigenous populations, such as the Aboriginal and Torres Strait Islander peoples or Māori, who are calling for the protection of their TK.

\footnotetext{
47 WIPO IGC Secretariat, Submission by Australia, Canada, New Zealand, Norway and the United States of America, WIPO Doc WIPO/GRTKF/IC/16/7 (2010).

48 WIPO IGC Secretariat, Compilation of Comments on WIPO/GRTKF/IC/16/7 'Submission by Australia, Canada, New Zealand, Norway and the United States of America', WIPO Doc WIPO/GRTKF/IC/17/INF/10 (2010), annexes 1 and 2.

49 Communication by the EC and its Member States to the TRIPS Council on the review of Article 27.3 (b) of the TRIPS Agreement, and the relationship between the TRIPS Agreement and the Convention on Biological Diversity and the protection of traditional knowledge and folklore, WTO Doc IP/C/W/383 (2002).

50 WIPO Doc, Disclosure of Origin or Source of Genetic Resources and Associated Traditional Knowledge in Patent Applications, WIPO Doc WIPO/GRTKF/IC/8/11 (2005).

51 WIPO IGC Secretariat, Proposal of the African Group on Genetic Resources and Future Work, WIPO Doc WIPO/GRTKF/IC/17/10 (2010).

52 Ibid, annex at 6.
} 


\section{EU Technical Assistance}

The Pacific Island states are among the beneficiaries of the Partnership Agreement ('Cotonou Agreement') between the members of the African, Caribbean and Pacific (ACP) group of states and the EU, signed 23 June 2000 and concluded for a twenty-year period from March 2000 to February 2020. Article 46 of the Cotonou Agreement recognises the need for parties 'to ensure an adequate and effective level of protection of intellectual, industrial and commercial property rights, and other rights covered by TRIPS including protection of geographical indications'.

During 2010, the EU executed two IPR technical assistance projects in the Pacific. The first, entitled 'Technical Assistance to the Pacific Regional Action Plan for Traditional Knowledge Development', had as its specific objective the provision of technical assistance for the establishment of national systems of protection for TK and EC in six of the member states of the Pacific Islands Forum, namely the Cook Islands, Fiji, Kiribati, Palau, Papua New Guinea and Vanuatu. ${ }^{53}$ A second project provided technical assistance to study the 'Feasibility of a Reciprocal Recognition and Enforcement Mechanism' for TK expressions of culture between Fiji, Papua New Guinea and the Solomon Islands: the so-called MSG countries. ${ }^{54}$

Under the first project, national mapping of TK and EC was conducted in the target states; draft IPR laws and policies have been formulated for Fiji, Papua New Guinea and the Solomon Islands; and a collaboration treaty was drafted for the MSG states. ${ }^{55}$ The treaty was submitted to the 18th Melanesian Spearhead Group Leaders' Summit in Suva on 31 March 2011, which 'agreed in principle pending decisions by members on the signing of the Treaty' ${ }^{56}$ The treaty was signed by the Governments of Fiji and the Solomon Islands in September $2011 .{ }^{57}$ The Governments of Papua New Guinea and Vanuatu are currently undertaking in-country consultations on the treaty before signing it.

The two EU projects concerned with TK were initiated as part of its assistance to be provided under the Cotonou Agreement, but interestingly TK is not a category of IPRs mentioned in the TRIPS Agreement. Another interesting feature of Article 46 of the Cotonou Agreement is that the only category of IPRs

\footnotetext{
53 Action Plan, above n 30.

54 TradeCom Facility Program, above n 31.

55 See M Blakeney, 'Protecting Traditional Knowledge and Expressions of Culture in the Pacific' (2011) 1(1) Queen Mary Journal of Intellectual Property 80.

56 18th Melanesian Spearhead Group Leaders' Summit, 'Communiqué' (2011) < http://www.msgsec.info/>

57 See Melanesian Spearhead Group, MSG Framework Treaty on Traditional Knowledge and Expressions

of Culture (2012) <http://www.msgsec.info/index.php?option=com_content\&view=article\&id=103:msgframework-treaty-on-traditional-knowledge-and-expressions-of-culture \&catid=39: $\mathrm{msg}$ culture \&Itemid $=162>$
} 
specifically mentioned is geographical indications (GIs). This is a category close to the heart of EU IPR interests, although it is something of a novelty for the Pacific Island countries. Given that the EU has not typically negotiated strongly for the protection of TK, its technical assistance to the Pacific Island countries in relation to TK might be regarded as the EU's price for garnering their support for its GIs agenda.

Resort to technical assistance from the EU in relation to TK is also explained in part by the slowness of developments in this area at WIPO, and by the perceived lack of enthusiasm for this subject on the part of Australia and New Zealand, countries which have traditionally provided technical legal assistance to Pacific Island countries.

\section{International Negotiations on Geographical Indications and the EU's Agenda}

Much closer to the interests of the EU are the WTO negotiations on GIs. Article 24.2 of the TRIPS Agreement requires the TRIPS Council to conduct a review of the operation of the GIs provisions within the first two years of entry into force of the WTO Agreement. The Council confined its initial review to the question of a multilateral register of geographical wine indications, as Article 23.4 provided that 'negotiations shall be undertaken in the Council for TRIPS concerning the establishment of a multilateral system of notification and registration of geographical indications for wines eligible for protection in those Members participating in the system'. Prior to the Ministerial Conference of the WTO held in Seattle in November 1999, a submission by Turkey proposed the extension of the multilateral register beyond wines and spirits. ${ }^{58}$ This was endorsed by the African group of countries which requested that the protection of GIs be extended 'to other products recognizable by their geographical origins (handicrafts, agro-food products)' ${ }^{59}$ This proposal was also taken up by Cuba, the Czech Republic, the Dominican Republic, Honduras, India, Indonesia, Nicaragua, Pakistan, Sri Lanka, Uganda and Venezuela. A proposal from Bulgaria, the Czech Republic, Egypt, Iceland, India, Kenya, Liechtenstein, Pakistan, Slovenia, Sri Lanka, Switzerland and Turkey was that the special protection for GIs in Article 23 be extended to products other than wines and spirits. ${ }^{60}$ Opposed to the proposals for an extension of the protection of GIs for wines

58 Preparations for the 1999 Ministerial Conference Agreement on TRIPS Extension of the Additional Protection for Geographical Indications to Other Products, WTO Doc WT/GC/W/249 (1999).

59 Preparations for the 1999 Ministerial Conference the TRIPS Agreement Communication from Kenya on Behalf of the African Group, WTO Doc WT/GC/W/302 (1999).

60 Geographical Indications - Communication From Bulgaria, The Czech Republic, Egypt, Iceland, India, Kenya, Liechtenstein, Pakistan, Slovenia, Sri Lanka, Switzerland and Turkey, WTO Doc IP/C/W/204/Rev.1 (2000). 
and spirits under TRIPS to all products, Argentina, Australia, Canada, Chile, Guatemala, New Zealand, Paraguay and the United States sent a communication to the TRIPS Council on 29 June 2001. ${ }^{61}$ It pointed out that proposals had insufficiently addressed the costs and administrative burdens of this extension. However, Clause 18 of the Doha Ministerial Declaration 2001 included within the negotiating subjects of the Round the establishment of a multilateral register for wines and spirits, as well as the extension of GI protection beyond wines and spirits as part of the Doha Development Agenda. ${ }^{62}$ As will be seen below, both sets of negotiations have proceeded without any perceivable progress. It is in this context that the EU has looked to enlist the support of the Pacific Island states for its negotiating positions.

In June 2005, the EC submitted a proposal to amend the TRIPS Agreement to provide global protection for GIs in a multilateral system of registration. ${ }^{63}$ This proposal sought to bring international protection for GIs into conformity with the EU, where a Community-wide system for their registration is considered an indispensable part of agricultural policy, serving both to preserve the incomes of small to medium-size producers and to guarantee the sustainability of the rural economy. Given that it possesses over 700 registered GIs, ${ }^{64}$ a sophisticated institutional infrastructure and technical prowess, the EU is exceptionally well placed to leverage the benefits of an expanded international system of GI protection. On the other hand, the United States and its supporters largely endorse the status quo, favouring voluntary multilateral registration and the choice of the means of protection - whether by special system or the established trade mark system — left to national discretion.

61 Geographical Indications - Communications from Argentina, Australia, Guatemala, Chile, Canada, New Zealand Paraguay and the United States, WTO Doc IP/C/W/289 (2001).

62 WTO Ministerial, Doha Declaration, WTO Doc, WT/MIN(01)/DEC/1 (2001), para 18 provides: “With a view to completing the work started in the Council for Trade-Related Aspects of Intellectual Property Rights (Council for TRIPS) on the implementation of Article 23.4, we agree to negotiate the establishment of a multilateral system of notification and registration of geographical indications for wines and spirits by the Fifth Session of the Ministerial Conference. We note that issues related to the extension of the protection of geographical indications provided for in Article 23 to products other than wines and spirits will be addressed in the Council for TRIPS pursuant to paragraph 12 of this Declaration.'

63 The EC proposed amending Section 3 of the TRIPS Agreement with a view to extending the regime of protection today available for GIs on wines and spirits to GIs on all products ('extension') and, in addition, a proposal for the inclusion of an annex to the TRIPS Agreement establishing a multilateral system of notification and registration of GIs. TRIPS Council, Special Session on Geographical Indications - Communication from the European Communities WTO Docs,WT/GC/W/547, TN/C/W/26, TN/IP/W/11 (2005). See earlier submissions of the EC, WTO Doc IP/C/W/107/Rev.1 (2000) with respect to the register, and submission in respect of the extension, Communication from Bulgaria, Cuba, Cyprus, The Czech Republic, The European Communities and their Member States, Georgia, Hungary, Iceland, India, Kenya, Liechtenstein, Malta, Mauritius, Pakistan, Romania, The Slovak Republic, Slovenia, Sri Lanka, Switzerland, Thailand and Turkey, WTO Doc IP/C/W/353 (2002).

64 'Since 1993, more than 700 names, designating inter alia over 150 cheeses, 160 meat and meat-based products, 150 fresh or processed fruits or vegetables and 80 types of olive oil, have been registered in this context. The Commission has also received over 300 further applications for the registration of names and/or amendments to specifications from Member States and third countries', see European Commission, Proposal for a Council Regulation on the Protection of Geographical Indications and Designations of Origin for Agricultural Products and Foodstuffs (Brussels, 2006), para.3. 
The EC submission set out provisions for a centralised register that would be compulsory and have legal effect. ${ }^{65}$ The EC proposal was aimed at preserving each WTO member's prerogative to determine whether a certain sign, indication or geographical name does indeed meet the TRIPS definition of a GI. ${ }^{66}$

Opponents of the EC proposal - Australia, Argentina, Australia, Canada, Chile, Ecuador, El Salvador, New Zealand and the US - took the position that the international protection of GIs is adequate as it stands, and that such a drastic development would serve only to undermine future gains in market access for non-European food and agricultural products. ${ }^{67}$ Concern was also expressed about the additional costs and administrative burdens of implementing a distinct system of GI protection in addition to the TRIPS obligations. These countries advocated a system of voluntary notification and registration, with no obligation to protect registered GIs. A revised communication from Argentina, Australia, Canada, Chile, Costa Rica, the Dominican Republic, Ecuador, El Salvador, Guatemala, Honduras, Japan, Korea, Mexico, New Zealand, Nicaragua, Paraguay, Chinese Taipei, South Africa and the US proposed that the TRIPS Council should set up a voluntary system whereby notified GIs would be registered in a database. Those governments choosing to participate in the system would have to consult the database when taking decisions on protection in their own countries. Non-participating members would be 'encouraged' but 'not obliged' to consult the database. ${ }^{68}$

Hong Kong, China proposed a compromise under which a registered term would enjoy a more limited 'presumption' than under the EU proposal, and only in those countries choosing to participate in the system. ${ }^{69}$

In July 2008, a group of WTO members called for a 'procedural decision' to negotiate three intellectual property issues in parallel: these two GI issues and a proposal to require patent applicants to disclose the origin of genetic resources or TK used in their inventions. ${ }^{70}$ WTO members remain divided over

65 Communication from the European Communities. The communication, dated, was circulated to the General Council, to the TNC and to the Special Session of the TRIPS Council at the request of the Delegation of the European Commission, Geographical Indications, above n 7. This proposal maintains the level of ambition of the EC as regards both 'extension' and the multilateral register of GIs, as contained in its earlier proposals in documents, above $\mathrm{n} 63$.

66 European Commission, above n 64, para 3.2(a).

67 See Communication from Argentina, Australia, Canada, Chile, Ecuador, El Salvador, New Zealand and the United States, WTO Doc TN/IP/W/9 (2004).

68 Submission by Argentina, Australia, Canada, Chile, Costa Rica, Dominican Republic, Ecuador, El Salvador, Guatemala, Honduras, Japan, Korea, Mexico, New Zealand, Nicaragua, Paraguay, the Separate Customs Territory of Taiwan, Penghu, Kinmen and Matsu, South Africa and the United States, WTO Doc TN/IP/W/10/Rev.2 (2008). 69 Multilateral System of Notification and Registration of Geographical Indications under article 23.4 of the TRIPS Agreement, WTO Doc TN/IP/W/8 (2003).

70 Communication from Albania, Brazil, China, Colombia, Ecuador, the European Communities, Iceland, India, Indonesia, the Kyrgyz Republic, Liechtenstein, the Former Yugoslav Republic of Macedonia, Pakistan, Peru, Sri Lanka, Switzerland, Thailand, Turkey, the ACP Group and the African Group, WTO Doc TN/C/W/52 (2008). 
the proposal to negotiate the three subjects in parallel, with opponents arguing that the only mandate for the TRIPS Council is to negotiate the multilateral register. Under the chairmanship of Ambassador Trevor C. Clarke (Barbados) during 2008 and 2009, the Special Session of the TRIPS Council considered the various proposals, and the chairman identified as 'crucial' the two issues of participation and consequences or legal effects of registration. ${ }^{71}$

With respect to the issue of whether participation in the system should be voluntary or mandatory, some WTO members interpreted the mandate's reference to 'a multilateral system' to mean that the system should apply to all members. Other members argued that the words 'those Members participating in the system' mean that not all members are expected to participate. Ambassador Clarke encouraged members 'to continue searching for an acceptable solution that would determine a participation of Members in the Register that renders it a useful and meaningful tool in line with its purpose to facilitate protection' ${ }^{72}$ With respect to the consequences or legal effects of registration, all members seem to accept an obligation to consult the information on the register and to take that information into account when making decisions regarding registration and protection of trade marks and GIs under their national procedures. However, views differ significantly as to how such information should be taken into account, what weight and significance should be given to it, and whether there should be a specific legal obligation to take the information into account.

Ambassador Clarke's successor as chairman of the Special Session of the Council for TRIPS, Ambassador Darlington Mwape (Zambia), announced upon assuming office that the specific negotiating mandate of the Special Session was limited to the negotiation of a register of GIs for wines and spirits. ${ }^{73}$ Ambassador Mwape circulated a work programme suggesting a list of 'Possible Elements for Developing Texts' for the future register. ${ }^{74}$ Applying this structure, a drafting group developed a single draft composite text on the register. ${ }^{75}$ Ambassador Mwape reported that despite the fact that this text reflects both the current state of negotiations in the group and significant progress, views differed on whether it could be forwarded to the Trade Negotiations Committee by Easter 2011, the deadline set by the Director-General of the WTO for the conclusion of the Doha Round of negotiations. ${ }^{76}$

\footnotetext{
71 WTO Report of Chairman, Multilateral System of Notification and Registration of Geographical Indications for Wines and Spirits, TN/IP/19 (2009), para 10.

72 Ibid, para 11.

73 WTO Report of Chairman, Multilateral System of Notification and Registration of Geographical Indications for Wines and Spirits, WTO Doc TN/IP/20 (2010), para 4.

74 See Multilateral System of Notification and Registration of Geographical Indications for Wines and Spirits, WTO Doc TN/IP/21 (2011).

75 That was circulated as WTO Doc JOB/IP/3 on 11 April 2011.

76 Ibid, para 16.
} 
Indigenous Peoples' Innovation

Ambassador Mwape explained:

I have made strenuous attempts to resolve this and have offered to use my prerogative as Chair to improve textual compliance with the Special Session of the Council for TRIPS mandate. However, Members have been unable to engage constructively on this question and have instead insisted that the purely bottom-up and Member-driven nature of the text be scrupulously respected at this time. ${ }^{77}$

His frustration would have been shared by the EU, given its desire to settle the issue of the multilateral register for its wines.

In view of the global markets at stake in the agricultural and food-processing sectors, the United States and Australia became so concerned at the systematic discrimination its trade mark owners faced in enforcing their rights against European-registered GIs that it invoked the WTO dispute settlement procedure. On 18 August 2003, the United States and Australia had requested the establishment of a WTO dispute settlement panel to review the consistency of the EU Regulation 2081/92 with the rules of the TRIPS and GATT Agreements. ${ }^{78}$ The US and Australia argued that the EU scheme for the protection of GIs failed to comply with TRIPS, principally because it was discriminatory in imposing additional registration obligations on non-EU nationals, and thus was in violation of the national treatment obligation which requires countries to treat foreigners in the same way as locals are treated.

The Panel Report in the dispute decided in favour of the US and Australia in relation to the national treatment argument. ${ }^{79}$ It recommended that the EU bring its regulation into conformity with the TRIPS Agreement by eliminating the additional registration requirements for foreigners. The EU Regulation was repealed and replaced by Council Regulation (CE) 510/2006 on the protection of GIs and designations of origin for agricultural products and foodstuffs.

The current position of New Zealand on GIs protection can be gleaned from the text of the Trans-Pacific Strategic Economic Partnership Partnership Agreement. ${ }^{80}$ It provides in Article 10.5 for the recognition of GIs for wines and spirits, those terms listed in Annex 10.A 'within the meaning of paragraph 1 of Article 22 of the TRIPS Agreement'. The Agreement makes no reference to the

\footnotetext{
77 Ibid, para 16.

78 See WTO Panel Report, European Communities - Protection of Trademarks and Geographical Indications for Agricultural Products and Foodstuffs, WTO Doc WT/DS174/20 (2005).

79 WTO Panel Report, European Communities - Protection of Trademarks and Geographical Indications for Agricultural Products and Foodstuffs, WTO Doc WT/DS290/R (2005).

80 This agreement between New Zealand, Chile, Singapore and Brunei is in force and has open accesion. It is the predecessor to the now wider Trans Pacific Partnership negotiaitons. Trans-Pacific Strategic Economic Partnership Agreement <http://www.mfat.govt.nz/downloads/trade-agreement/transpacific/main-agreement.pdf >
} 
extended protection for wines and spirits envisaged in Article 23 of TRIPS, and the terms contained in Annex 10A comprise only Chilean GIs, suggesting the reluctance of the other negotiating parties to embrace this form of protection.

The current position of the United States (and probably of Australia) on GIs protection can be gleaned from the leaked draft negotiating text of the Trans Pacific Partnership negotiations. ${ }^{81}$

Finally, it should be noted that despite the commitment of the EU to GIs, their utilisation seems to be limited to agricultural enterprises in France, Italy, Spain and Portugal. In 2006 the EC announced a review of its system for the protection of GIs, including an evaluation of trade marks as an alternative instrument for the protection of GIs. ${ }^{82}$ The subsequent 'Green Paper on Agricultural Product Quality' of 2008 and 'Impact Assessment Report on Agricultural Product Quality Policy' of 2009 endorsed the complementary roles of trade marks and GIs in protecting agricultural products. ${ }^{83}$

\section{The EU, Gls and the ACP Countries}

As mentioned above, Article 46 of the Cotonou Agreement between the members of the African, Caribbean and Pacific (ACP) group of states recognises the need for parties to ensure an adequate and effective level of protection for IPRs 'including protection of geographical indications'. This obviously supports the EU's own negotiating priorities. In an endeavour to generate empirical evidence about the value of GIs for ACP countries, the EU has commissioned a project

to generate empirical evidence, based on country/sub-regional and product case studies, regarding the benefits that African members of the ACP Group can obtain from enhanced multilateral Geographical Indication (GI) protection as a basis for the African Group to engage in the Doha negotiations on the establishment of the multilateral register for wines and spirits and the proposed extension of protection to products other than wines and spirits under Article 23 of TRIPS. ${ }^{84}$

\footnotetext{
81 See The complete Feb 10, 2011 text of the US proposal for the TPP IPR chapter <http://keionline.org/ node/1091>

82 See G Evans, 'The Comparative Advantages of Geographical Indications and Community Trademarks for the Marketing of Agricultural Products in the European Union' (2010) 41 IIC-International Review of Intellectual Property 645.

83 European Commission, Green Paper on Agricultural Product Quality: Product Standards, Farming Requirements and Quality Schemes (Brussels, 2008) 13; European Commission, Agricultural Product Quality Policy: Impact Assessment, Part B, Geographical Indications (2009) 4-5.

84 Action Plan, above n 30.
} 
The countries studied in January to March 2011 were: Cameroon, Gabon, Ghana, Nigeria and Senegal in West and Central Africa; and: Kenya, Mauritius, Rwanda and Tanzania in East and Southern Africa. ${ }^{85}$

The project was designed to produce 'a replicable methodology for analysing the dynamics of capturing economic value out of GIs; access to GI-protected products by local populations; the role of government in the GI framework; the costs of establishing and administering a GI regime in a country; and the costs of developing, registering and enforcing individual GIs' ${ }^{86}$ What the project established was that most of the countries surveyed had enacted GIs legislation but that it had not yet come into effect, with the result that industries were relying primarily on certification or collective trade marks to protect their geographical brands. However, a number of EU-funded projects are under way in Africa to build institutional competence to underpin GIs protection for Oku white honey and Penja white pepper from Cameroon; Dogon onions from Mali; and attiéké and Korhogo cloth from Côte d'Ivoire. The first country to protect GIs in Africa is Morocco, where argan oil and products of argan trees have been registered.

In February 2010, WTO Director-General Pascal Lamy, who was formerly head of the EC's Directorate General of Trade, explained that 'the Doha Round will help level the playing field for Africa, correcting historical injustices in the world trade rule-book' ${ }^{87} \mathrm{He}$ also said that 'African agriculture needs to become more efficient, and in that efficiency it needs to discover "specialization". In other words, the WTO, in the same way as the EU, perceives that GIs are a useful adjunct to the promotion of agricultural trade.

\section{Protecting TK through Gls}

In the absence of an international regime to protect TK, existing categories of intellectual property have sought to be applied to its protection. As Panizzon and Cottier observed:

Traditional Knowledge (TK) and Geographical Indications (GIs) share a common element insofar as they both protect accumulated knowledge typical to a specific locality. While TK expresses the local traditions of knowledge, GIs stand for specific geographical origin of a typical product

85 Industries studied were: Cameroon — Oku white honey; Gabon — Okoumé timber; Ghana — cocoa; Kenya — black tea; Mauritius — Demerara sugar; Nigeria — yams; Rwanda — coffee; Senegal — yêtt de Joal; Tanzania - cloves.

86 Action Plan, above n 30.

87 Opening the conference on Harnessing Agriculture for Development through Trade in Geneva (2011)

$<$ http://www.wto.org/english/news_e/sppl_e/sppl188_e.htm> 
or production method. GIs and TK relate a product (GIs), respectively a piece of information (TK), to a geographically confined people or a particular region or locality. ${ }^{88}$

Similarly, in its Review of Existing Intellectual Property Protection of Traditional Knowledge, ${ }^{89}$ the IGC Secretariat observed that:

Geographical Indications as defined by Article 22.1 of the TRIPS Agreement and appellations of origin, as defined by Article 2 of the Lisbon Agreement ... rely not only on their geographical connotation but also, essentially, on human and/or natural factors (which may have generated a given quality, reputation or other characteristic of the good). In practice, human and/ or natural factors are the result of traditional, standard techniques which local communities have developed and incorporated into production. Goods designated and differentiated by geographical indications, be they wines, spirits, cheese, handicrafts, watches, silverware and others, are as much expressions of local cultural and community identification as other elements of traditional knowledge can be..$^{90}$

Three examples provided by the IGC Secretariat of traditional knowledge protected by geographical indications are: 'Cocuy the Pecaya' liquor from Venezuela, and 'Phu Quoc' fish sauce and 'Shan Tuyet Moc Chau' tea, both from Vietnam.

On the other hand, Kur and Knaak observe that:

The indication for a product is the subject matter of this protection, not the product itself. For this reason tradition-based innovations and creations, as indicated in the WIPO Report on Fact-finding Missions on Intellectual Property and TK, cannot enjoy protection per se by means of geographical indications. The protection of GIs may apply only to signs indicating these innovations and creations. ${ }^{91}$

This is unquestionably the case, but it has been pointed out that all GIs whether 'Champagne' wine, 'Parma' ham or 'Roquefort' cheese, protect not only the use of the indication but also the innovations which stand behind the indication. ${ }^{92}$ Indeed, one of the functions of trade marks is that they act as a warranty of quality as well as an indication of the source of a product.

\footnotetext{
88 S Biber-Klemm and T Cottier, Rights to Plant Genetic Resources and Traditional Knowledge: Basic Issues and Perspectives (CAB International Publishing, 2006) 82.

89 WIPO IGC Secretariat, Review of Existing Intellectual Property Protection of Traditional Knowledge, WIPO Doc WIPO/GRTKF/IC/3/7 (2002).

90 Ibid, para 40.

91 A Kur and P Knaak, 'Protection of Traditional Names and Designations' in SV Lewinski (ed) Indigenous Heritage and Intellectual Property: Genetic Resources, Traditional Knowledge, and Folklore (Kluwer Law International, 2004) 221, 227.

92 M Blakeney, 'Protection of Traditional Knowledge by Geographical Indications' (2009) 3(4) International Journal of Intellectual Property Management 357, 361.
} 
Kur and Knaak also reject the possibility that 'kava' from the Pacific region and 'rooibos' from South Africa could be protected as 'they are not GIs per se as they have no direct geographical meaning'.$^{93}$ This interpretation appears to overlook the jurisprudence on indirect GIs. For example, the European Court of Justice held 'feta' to be a GI for cheese coming from Greece, even though there is no geographical place of that name, ${ }^{94}$ and the UK Intellectual Property Rights Commission suggested that 'Basmati' might be registered as a GI to protect rice from India andPakistan. ${ }^{95}$ Thus, on the same basis, 'kava' and 'rooibos' might be taken as indirect indications of the places from which they come.

Among the strengths of GI protection is that it might provide for protection of TK which is already in the public domain. For example, in relation to kava, the United States Patents and Trade Marks Office granted Natrol, Inc., a US-based company, a US patent for 'kavatrol', a dietary supplement composed of kava that serves as a general relaxant. ${ }^{96}$ Two German companies, William Schwabe and Krewel-Werke, obtained a patent for kava as a prescription drug for treating strokes, insomnia and Alzheimer's disease. ${ }^{97}$ In France, L'Oréal has patented the use of kava against hair loss. ${ }^{98}$ As these products are promoted on the basis of their derivation from kava, GIs may prove to be the second best option for protecting kava by acting as a substitute for patent protection of the TK related to the plant itself. ${ }^{99}$

From 26 to 28 August 2010, the EU-ACP organised a regional workshops on the protection of GIs and TK in the Pacific. This meeting, held in Nadi, Fiji, replicated similar events organised by the ACP-EU in Douala, Cameroon; Cape Town, South Africa; and Port of Spain, Trinidad. A particular feature of the Nadi meeting was establishing the linkage between GIs and TK protection, including cultural products. Potential GI products in the Pacific region which were identified at the workshop included: fine mat weaving from Tonga, the Cook Islands and Tokelau; decorative weaving from Fiji; floor mats from Papua

\footnotetext{
93 Kur and Knaak, above n 91, 228.

94 Federal Republic of Germany and Kingdom of Denmark $v$ Commission of the European Communities (2005) European Court of Justice, Joined Cases C-465/02 and C-466/02.

95 UKIPR Commission, Integrating Intellectual Property Rights and Development Policy (UKIPR, 2002) 89; see also G Giraud, 'Range and Limit of Geographical Indication Scheme: The Case of Basmati Rice from Punjab, Pakistan' (2008) 11 International Food and Agribusiness Management Review 1.

96 D R Downes and S A Laird, Innovative Mechanisms for Sharing Benefits of Biodiversity and Related Knowledge Case Studies on Geographical Indications and Trademarks (1999) < http://www.ciel.org/Publications/ InnovativeMechanisms.pdf>

97 M Panizzon, 'Traditional Knowledge and Geographical Indications: Foundations, Interests and Negotiating Positions' (Working Paper No. 2005/01 2006) < http://phasel.nccr-trade.org/images/stories/publications/IP8/ Traditional\%20Knowledge.pdf 151>

98 Ibid.

99 It should be noted that the importation of kava to the EU had been prohibited on health grounds until 2009. See K Hoyumpa and L Schmiere, Europe lifts kava ban and south Pacific hopeful for resumed kava trade (2009) <http://www.nakamalathome.com/blog/europe-lifts-kava-ban-and-south-pacific-hopeful-forresumed-kava-trade.html>
} 
New Guinea; Solomon Islands baskets; carving from Papua New Guinea and the Cook Islands; bilum (string bag) products from Papua New Guinea; and kava from Fiji.

On the other hand, it has been forcibly pointed out by Susy Frankel that GIs are not co-terminous with TK, and it would be a mistake to assume that GIs protection could perform the same function as sui generis TK protection. ${ }^{100}$ She observes that the French appellations des origins controlées system does not protect the TK of the producers of traditional products but protects only 'the name for use by those whom the associated bureaucracy deems merit worthy of its use' ${ }^{101}$ Also, it has been acknowledged that TK admits of dynamic development, whereas GIs are a static form of intellectual property fixed at the time of registration. Frankel asserts that GIs have been 'oversold as tools of development', since they are 'not in fact developmental in any innovative way, but are rather tools of maintaining the status quo' and 'the creation of a GI is not going to suddenly open greater markets for the knowledge held and products produced by indigenous peoples' ${ }^{102}$ However, as has been pointed out above, in the absence of TK protection - an absence which may persist for many years, given the glacial pace of progress at WIPO - GIs are only to be regarded very much as a second best solution. Frankel's strictures are a useful warning against acceptance of the current unsatisfactory state of affairs.

\section{Conclusion}

Although this chapter seeks to argue that the EU's Pacific agenda in relation to technical assistance concerning TK should be observed through the EU's GIs spectacles, there is, of course, a much broader economic perspective which has to be taken into account. EU development cooperation is provided to the Pacific Island countries in the context of the Cotonou Partnership Agreement between the EU and the African, Caribbean and Pacific states (ACP). The EU as an integrated regional entity prefers to deal with other regions wherever possible. ${ }^{103}$ This is probably because of its comparative advantage in regionalism and the greater efficiency of dealing with, for example, six sub-groups within the ACP rather than negotiating seventy-eight bilateral partnership agreements. ${ }^{104}$

\footnotetext{
100 S Frankel, 'The Mismatch of Geographical Indications and Innovative Traditional Knowledge' (2011)

29(3) Prometheus 253.

101 Ibid, 262.

102 Ibid, 267.

103 See P Lamy, 'Stepping Stones or Stumbling Blocks? The EU's Approach Towards the Problem of Multilateralism vs Regionalism in Trade Policy' (2002) 25(10) The World Economy 1399.

104 See S Thomas, EUphoria in the Pacific? Regional Economic Partnership Agreements - Implications for the Pacific (Paper presented at the New Zealand Asia Pacific European Studies Association Conference 'Outside Looking In', Christchurch, 2004) <http://www.europe.canterbury.ac.nz/conferences/apeu2004/papers/thomas.pdf >
} 
Any EU technical assistance must be viewed in the context of its regionalisation agenda. From 2008, a number of EPAs have been entered into between the EU and a number of groups of ACP countries. The EPAs will succeed the trade provisions of the Cotonou Agreement. By way of example, in the draft proposals with the Economic Community of West African States and Southern African Development Community, substantive obligations are proposed in the areas of copyright and related rights, trade marks, GIs, industrial designs, patents, plant varieties and IPR enforcement, in exchange for trade liberalisation and development assistance.

Matters are not as far advanced in the Pacific. In July 2009, Papua New Guinea signed an interim EPA with the EU, and Fiji signed an interim EPA with the EU in December 2009. The details of these EPAs are yet to be worked out, but following the African precedents, they will probably include provisions dealing with IPRs, including GIs.

Paralleling the EU's EPAs, Trans-Pacific Partnership Agreement (TPP) negotiations commenced in March 2010 in Melbourne, with the participation of Australia, Brunei, Chile, New Zealand, Singapore, Peru, the United States and Vietnam. Malaysia joined at the third round of negotiations in October 2010. The second sentence of Article 10.5.1, which deals with GIs, provides that '[s]ubject to domestic laws, in a manner that is consistent with the TRIPS Agreement, such terms will be protected as geographical indications in the territories of the other Parties.' The footnote to this provision states, for greater certainty, 'the Parties acknowledge that geographical indications will be recognised and protected in Brunei Darussalam, Chile, New Zealand and Singapore only to the extent permitted by and according to the terms and conditions set out in their respective domestic laws'. Presumably, Australia and the United States are not yet willing to acknowledge the existence of GIs, or they take comfort from the fact that their GIs are already protected by certification and collective marks.

Article 10.3.3 of the TPP provides that subject to each party's international obligations, the parties affirm that they may '(d) establish appropriate measures to protect traditional knowledge'. 